\title{
FORUM
}

Submitted 05.10.2017. Approved 02.05.2018.

Evaluated by double blind review process.

DOI: http://dx.doi/10.12660/joscmv11n1p64-79

\section{THE ROLE OF COLLABORATION FOR RESILIENCE OF THE SUGARCANE-ENERGY SUPPLY CHAIN}

\begin{abstract}
The drought in the sugarcane-energy supply chain of São Paulo occurred between 2014 and 2015 was the phenomenon observed in this case study whose starting point was the following question: how can collaboration bring on resilience in supply chains experiencing a disaster? Deductive qualitative approach has empirically contributed to the knowledge of possible disruptions focused on the agribusiness. For those purposes, aspects involving vertical (suppliers, focal company and buyers) and horizontal (NGOs, government, research centers, focal company and their competitors) collaboration was analyzed among the links of the chain (triad: farmers, processers and buyers). Vertical collaboration between buyers and focal company, if compared to that of focal company and suppliers (the weakest link) is more significant. The findings in this study, however, should be considered solely within the context of the supply chain analyzed once new researches in different cultures of the agribusiness, regions and types of disasters have yet to be done.
\end{abstract}

KEYWORDS | Agribusiness, case study, risks, disruptions, droughts.

Marcelo Martins de Sá

professormarcelosa@gmail.com

Susana Farias Pereira

susana.pereira@fgv.br

Priscila Lacsynski de Souza Miguel

priscila.miguel@fgv.br

Fundação Getulio Vargas, Escola de Administração de Empresas de São Paulo, São Paulo, SP, Brazil 


\section{INTRODUCTION}

Cost increase caused by disruptions in supply chains has led researchers and professionals to question the traditional risk- management approach where elaborating mitigation strategies is based on assessing the probability of an event and on how serious the impact is expected to cause (Jüttner \& Maklan, 2011; Pettit, Croxton, \& Fiksel, 2013; Pettit, Fiksel, \& Croxton, 2010). That is so because along the last years researches on risk management have targeted on identifying risk sources through a proactive vision based on forecasting possible events able to cause disruptions (Jüttner, 2005; Punniyamoorthy, Thamaraiselvan, \& Manikandan, 2013; Sodhi \& Lee, 2007; Stecke \& Kumar, 2009): "The focus of business toward increasing efficiency and reducing costs has resulted in supply chains that are efficient during normal times, but at the cost of being vulnerable to disruptions. From time to time, frequent as well as rare catastrophes also disrupt supply chain operations. We collect and compile data from many sources and show that there has been a marked increase in both the frequency and economic losses from natural and man-made catastrophes. We find that business losses constitute a major percentage of the total losses caused by these catastrophes. The statistics suggest that for terrorist attacks, the vulnerability of U.S. business interests is much higher than others. Examination of the geographical and chronological distributions of catastrophes provides useful information for managers concerned about such disruptions. We develop a catastrophe classification framework that matches different types of catastrophes to a variety of infrastructural components of supply chains. The framework also connects a variety of mitigating strategies to appropriate catastrophe types. We identify factors that can be used to assess the vulnerability of a supply chain. They can also be useful to compare possible alternative decisions based on the vulnerability they may cause in the supply chain. To manage vulnerability in supply chains, we propose strategies that can be implemented by a company to decrease the possibility of occurrence, provide advance warning, and cope after a disturbance. We reveal potential benefits from mitigating strategies during normal times, which indicate that well-developed strategies can also result in better efficiency. We identify many future research areas concerning disruption handling in supply chains. [ABSTRACT FROM AUTHOR] Copyright of Journal of Marketing Channels is the property of Taylor \& Francis Ltd and its content may not be copied or emailed to multiple sites or posted to a listserv without the copyright holder's express written permission. However, users may print, download, or email articles for individual use. This abstract may be abridged. No warranty is given about the accuracy of the copy. Users should refer to the original published version of the material for the full abstract. (Copyright applies to all Abstracts..

That vision, however, can be limited when organizations and supply chains are not able to realize in advance and efficaciously unexpected events; or yet risks that despite being foreseen inevitably cause serious disruptions without low mitigation potential (Pettit et al., 2013). That is why, based on the assumption that some risks are unpredictable, organizations and their supply chains need to build up resilience when facing rare and uncertain events (Knemeyer, Zinn, \& Eroglu, 2009; Pettit et al., 2010) by adding to their forecast proactive vision actions able to trigger reactions of response and post-impact recovery.

Resilience has been defined within organizational environments as the capacity of going beyond absorbing an impact and recovering from it, and it also incorporates the capacity of adapting and building up flexibility. Due to the interconnection in supply chain networks, organizations' interdependence can increase consequences of disruptions thus making resilience be extended at that the level of that chain (Ponomarov \& Holcomb, 2009; Tukamuhabwa, Stevenson, Busby, \& Zorzini, 2015; Wieland \& Wallenburg, 2013) in order to ensure continuity of operations and delivery of goods to buyers (Ambulkar, Blackhurst, \& Grawe, 2015; Christopher \& Peck, 2004).

Resilience in supply chains (SCR) is an incipient, fragmented area of research, despite a promising one (Ali, Mahfouz, \& Arisha, 2017; Blackhurst, Dunn, \& Craighead, 2011; Kamalahmadi \& Parast, 2016), in spite of the still limited number of the existing empirical researches (Kamalahmadi \& Parast, 2016; Tukamuhabwa et al., 2015). In this sense, although there is an increasing body of literature on resilience definitions, it is still outdated related to the approach of the strategies to be implemented beyond the organizations' borders, of its diversification and verification of existence of synergies or trade-offs among them (Tukamuhabwa et al., 2015).

A possible strategy for supply chains' resilience should take into consideration redundancy and multiple suppliers as a way of limiting both disruption and effects in sequence (Rice \& Caniato, 2003; Tukamuhabwa et al., 2015). An alternative to that could be collaboration between buyers and suppliers involving shared 
resources for their mutual benefit (Pettit et al., 2013; Zacharia, Nix, \& Lusch, 2009). In spite of the potential success of both strategies, maybe they are not viable in all situations or for all links of a supply chain.

Literature on SCR contains few investigations that consider at least the triad composing supply chains, in this case farmers, processers and buyer, as the unit to be analyzed (Hahn, Pinkse, Preuss, \& Figge, 2015; Odongo, Dora, Molnár, Ongeng, \& Gellynck, 2016). Although the concept is discussed within organizations, networks and supply chains (Ali et al., 2017), we have to understand how organizations build up resilience and its impact on supply chains (Kamalahmadi \& Parast, 2016).

To understand the different organizational strategies to mitigate, prepare, respond and recover from serious disruptions impacting on a supply chain's final performance, this study was based on the following research question: how can collaboration bring on resilience in supply chains experiencing a disaster?

Although the understanding of collaboration stands for a main topic for practices of risk management in supply chains, SCR literature lacks empirical insights approaching beyond the perspective of one single organization (Scholten, Schilder, \& Wagner, 2015).

For the purposes of filling up this theoretical gap, pointed out Scholten et al. (2015), this study intended to analyze how collaboration activities among members of the sugarcane-energy supply chain have been able to increase their resilience even when experiencing several risks and disruptions in the drought occurred between 2014 and 2015. It is worth stressing that despite the problems experienced, that chain has remained competitive when compared to other commodities used to produce foods, fuels or energy.

In addition to its economic, social and environmental relevance added to its historical vulnerability resulting from a myriad of threats (governmental interference with prices and products' characteristics, laborrelated issues similar to slavery, bad soil conservation in agricultural areas, intensive dependence on water resources in the industrial area, among others), up to this date no researches have been published on the theme of resilience and its empirical contributions in the agribusiness sector in Brazil. This equally evidences the academic relevance of this study for the national scenario once recently there has been several productive discussions about the sugarcane-energy supply chain (Aquila, Pamplona, Queiroz, Junior, \&
Fonseca, 2017; Biazzin, Paiva, Di Serio, \& Andrade, 2015; Brunhara, Corrêa, \& Mazini, 2018; Dias et al., 2015; Fuess, Rodrigues, \& Garcia, 2017; Julca-Briceño \& Fava Neves, 2011).

This article has been structured in five sections, starting with this introduction (first section). Next are presented: theoretical foundation based on literature review on the capacity of collaboration for resilience in supply chains and types of collaboration (second section); the research methodology step-by-step by using a qualitative approach by means of case study (third section); the findings emphasizing the information arising from the participant's speeches gathered in interviews and analyzed by means of data triangulation, and also in other sources of information such as documents, reports and observations made in field visits, in addition to discussions among the authors of this study (fourth section); and, finally, final considerations including the research's limitations and suggestions for future studies (fifth section), followed with the list of references of the works quoted.

\section{THEORETICAL FOUNDATION}

It was chosen to work with the capacity of collaboration once formative elements of resilience in supply chains should be adopted by all members targeting on joining strengths in case of a risky event (Jüttner \& Maklan, 2011). As Supply Chain Resilience (SCR) is a concept that exceeds an organization's limits, it becomes insufficient as an efficacious strategy able to search for flexibility, speed, visibility or other capacities which singly compose resilience.

To develop a broad strategic network of flexibility and to reduce the uncertainty it is important to build up collaborative relationships among all links of a supply chain (Stevenson \& Spring, 2007). Sometimes a relationship may cause direct conflicts because maintaining a long-term contract with a supplier my help decreasing uncertainty, increase trust and willingness to adopt small changes, provided that an arms-length relationship is maintained - thus minimizing suppliers' dependence and maximizing bargaining power (Dyer \& Singh, 1998).

Dyer and Singh' analysis (1998, p. 662) suggests that alliances among companies only result in competitive advantage if there is a relationship with additional characteristics to those attributed to that market by means of different capacities existing in the respective supply chains. 
The study authors propose four more common categories in studies involving supply chains. Relationship-specific assets, represented by specialized assets together with the assets of a partner. Informationsharing routines where regular interaction patterns are used which enable transferring, recombining or creating specialized knowledge. Complementary resources and capacities identified in partners' assets which collectively bring about more benefits than the sum of the assets obtained from individual agreements with each partner. Finally, effective governance understood as a set of mechanisms used to align diverging interests of partners in a supply chain aiming at minimizing transactions' costs and maximizing the value of the agreement through cooperation (Dyer \& Singh, 1998; Paulraj, Chen, \& Lado, 2012).

\section{Exhibit 1. Four Categories Determining Collaboration and Facilitating sub-processes}

\begin{tabular}{|c|c|c|}
\hline $\begin{array}{l}\text { Collaboration determining } \\
\text { factors }\end{array}$ & Relationship description & Facilitating sub-processes \\
\hline Relationship-specific assets & $\begin{array}{l}\text { Specialized assets together with a } \\
\text { partner's assets }\end{array}$ & $\begin{array}{l}\text { - Duration of contractual guaranties } \\
\text { - Volume of transactions among } \\
\text { companies }\end{array}$ \\
\hline Information-sharing routines & $\begin{array}{l}\text { Regular interaction patterns } \\
\text { enabling transferring, recombining } \\
\text { or creating specialized knowledge }\end{array}$ & $\begin{array}{l}\text { - Absorbing capacity of a partner } \\
\text { Incentives to encourage } \\
\text { transparency and discourage free } \\
\text { agreements }\end{array}$ \\
\hline $\begin{array}{l}\text { Complementary resources and } \\
\text { capacities }\end{array}$ & $\begin{array}{l}\text { The partners'assets that collectively } \\
\text { bring on bigger benefits than } \\
\text { the sum of those obtained from } \\
\text { individual agreements with each } \\
\text { partner }\end{array}$ & $\begin{array}{l}\text { - Capacity to identify and assess } \\
\text { complementarities' potential } \\
\text { - Role of organizational } \\
\text { complementarities to access } \\
\text { complementary strategic } \\
\text { resources }\end{array}$ \\
\hline Effective governance & $\begin{array}{l}\text { The set of mechanisms used to align } \\
\text { diverging interests of the partners } \\
\text { in the Supply Chain in order to } \\
\text { minimize transaction costs and } \\
\text { maximize the value of agreements } \\
\text { made through cooperation }\end{array}$ & $\begin{array}{l}\text { - Capacity to use self-application } \\
\text { instead of application by third } \\
\text { parties of the governance } \\
\text { mechanisms } \\
\text { - Capacity to use formal and } \\
\text { informal self-applicable } \\
\text { governance mechanisms }\end{array}$ \\
\hline
\end{tabular}

Source: Adapted (Dyer \& Singh, 1998; Paulraj et al., 2012)

As to the supply chain, collaboration can be defined as a partnership process aimed at planning and carrying out the chain's operations to obtain mutual benefits (Cao \& Zhang, 2011)firms have strived to achieve greater supply chain collaboration to leverage the resources and knowledge of their suppliers and customers. The objective of the study is to uncover the nature of supply chain collaboration and explore its impact on firm performance based on a paradigm of collaborative advantage. Reliable and valid instruments of these constructs were developed through rigorous empirical analysis. Data were collected through a Web survey of U.S. manufacturing firms in various industries. The statistical methods used include confirmatory factor analysis and structural equation modeling (i.e., LISREL. Collaboration capacity stands for the level of decisions shared and joint work at tactical, operational and strategic levels, between two or among more members of the supply chain (Zacharia et al., 2009), regardless of the position they occupy therein.

Specifically in the agribusiness case collaboration is adequate to minimize costs, increase profits, to meet quality requirements and, should those results be positive, to gain buyers' trust (Prima Dania, Xing, \& Amer, 2016). Collaboration involves all activities, such as production processes, information sharing, infrastructure, capacities and knowledge in the agribusiness chain links: farmers, processers, distribu- 
tors, retailers, cooperatives, governmental agencies, NGOs and input suppliers, including financial ones.

Holding the definition above as starting point, Cao and Zhang (2011) developed a list with six main characteristics: (1) information sharing, (2) congruence of goals, (3) in-synch decisions, (4) alignment of incentives, (5) collaborative communication and (6) joint creation of knowledge among partners in the supply chain. Nyaga et al. (2010) summarize this understanding in just three priority factors: (1) information sharing, (2) efforts for joint relationship and (3) dedicated investments.

When dealing with risk and resilience in supply chain, collaboration is influenced by the existence of proper systems of management and by following up the performance by means of plans integrating the chain (Leat \& Revoredo-Giha, 2013). This implies suppliers, focal company and buyers coming closer to each other, (vertical collaboration), involvement of partners at the same level in the chain, such as competitors, NGOs, Government or even other supply chains (horizontal collaboration) (Barratt, 2004).

A study on vertical collaboration in African sugarcane-energy supply chains shows that aspects of the organizational behavior, such as commitment, trust and cooperation, are relevant to maintain contractual relationships (Masuku, Kirsten, Rooyen, \& Perret, 2003). In that assessment, in the producersplants dyad, Masuku et al. (2003) highlight that individuals' trust is more important than contractual relationships.

Still according to the authors mentioned above, two pillars were highlighted: management of configurations and management of the relationships in the sugarcane-energy supply chain, once both attest the need of more flexibility in the supply chain because collaboration performs an essential role in enabling new configurations among the links of that chain and, moreover, based on the relationship, those structures can be shared (Masuku et al., 2003).

After the literature review on collaboration in agribusiness chains, Prima Dania et al. (2016) highlight the relevance of interaction among producers-plant owners when they state that inefficiency tends to be caused by small and behavioral problems instead of matters demanding structure (Prima Dania et al., 2016). Additionally, local autonomy is crucial to support the relationship between farmers and local plants (Prima Dania et al., 2016).
Therefore, interaction among farmers, processers and buyers in agribusiness chains points out that different interests, goals, levels of power (such as access to credit, for instance) and perspectives of future become obstacles for creating a satisfactory collaboration (Prima Dania et al., 2016).

Keeping collaboration along all phases of the supply chain is rather complex because the more stakeholders participate in the collaborative system, the more difficult it becomes (Prima Dania et al., 2016). Without collaboration, however, the price for buyers would be higher once at each phase of the chain values would be increased for the purposes of decreasing risks and increasing benefits (Prima Dania et al., 2016).

\section{METHODOLOGY}

Holding the sugarcane-energy supply chain defined as analysis unit, the method used was case study, which aimed at investigating how organizations occupying different positions in the supply chain used collaboration to build up resilience when experiencing the disruptions resulting from a natural phenomenon - the drought, occurred between 2014 and 2015 in the state of São Paulo.

Although disruptions caused by hydrological factors (droughts or floods) are known in Brazil, for the southeastern region there had not been any precedents for the last five decades (de Almeida, Welle, \& Birkmann, 2016; Nobre, Marengo, Seluchi, Cuartas, \& Alves, 2016; Pivetta, 2016b, 2016a)visualise and communicate different levels of exposure, vulnerability and risk in Brazil. The index may sensitise public and political decision-makers towards the important topic of disaster risk and climate change adaptation. This article aims to explore the feasibility and usefulness of such a national risk index that considers both natural hazard phenomena and social vulnerability. The exposure to natural hazards was assessed by using four indicators that describe the exposure of people towards landslides, floods, droughts and sea level rise. Whereas vulnerability dimension consists of susceptibility, coping capacity and adaptive capacity was calculated on the basis of 32 indicators which comprise social, economic and environmental conditions of a society. The county comparison provides an initial ranking of exposure and vulnerability. Specific analysis of coping and adaptation capacities also indicates that risk or vulnerability are not pre-defined conditions, but rather are constructed by societies exposed to natural hazards. The results of the DRIB Index were mapped and 
classified by means of a GIS system to show different patterns of exposure, vulnerability and risk on global scale. The national perspective of risk clearly shows that the vulnerability of a society or a country is not the same as exposure to natural hazards. The information provided by the DRIB Index highlights the need for preventive measures towards Disaster Risk Reduction and Climate Change Adaptation in the country as a whole, but also at regional and local scales. The results showed that the risk is strongly interwoven with social-economic and cultural conditions and normal everyday life, as well as with the performance of state institutions dealing with Disaster Risk Reduction (DRR. That region, where rains are regular, represents the main area for sugarcane cultivation in the country considering the abundance of hydrographic basins, which results in strong concurrence of hydric resources for agricultural and industrial production and supply for highly populated cities.

Analyzing organizations in different links of the sugarcane-energy supply chain composed by the farmers, processers (plants and distilleries) and buyers tried, in addition to cooperatives, research centers and associations representing the sugarcane-energy sector, was the objective of this simple case study. The organizations were screened according to a theoretical sampling process based on their capacity of rendering information on the matter (Eisenhardt, 1989). The data collected and analyzed involved 24 organizations, one sector-relevant association and an agribusiness-related governmental agency.

As the interviews were conducted, managers were requested to supply additional companies according to their relationships within the supply chain. The data were collected in two different periods: from July to November 2015 and from July to December 2016. All participants in the first phase of interviews were heard again in the second phase of the data collection (except farmer and processer 3 ).

The interviews followed a research protocol involving semi-structured questions previously prepared. Initially, after the first results had been analyzed, that protocol was adjusted and questions were added in order to increase our understanding of the supply chain (Ali et al., 2017). In the second round of interviews the initial cases were reviewed a total of 39 semi-structured interviews were considered.

The key-informants in charge of the operations (managers and directors of agriculture or operations and farmers), who had over 03-year professional experience in the participating organization, were searched targeting on ensuring the information coming from their experience in their respective organizations and on understanding the intensity of the impacts suffered from the phenomenon that created the disruption.

Finally, consultants of sector associations and governmental agencies were interviewed to enhance and verify the information obtained. The sample was composed of five farmers, 13 processers (12 out of those with their own agricultural production - vertically integrated), two cooperatives (one of producers and one of buyers), three plants (two of soft drinks and one of foods), one sector association and one governmental agency. Thus, the sample contains various organizations with different sizes and occupying different positions in the supply chain once that is the context able to influence the capacity of resilience (SullivanTaylor \& Branicki, 2011). Exhibit 2 presents the characterization of the companies composing the sample as to their position in the supply chain, the titles of their informants and for how long they had worked in the participating company and its location.

Exhibit 02. Samples of Participants in Data Collection

1a Phase of Collection

\begin{tabular}{l|l|l|l|l|l}
\hline Chain links & Date & Interview type & Respondent position & Experience & City \\
\hline Government 01 & $07 / 10 / 15$ & In person & Director & 24 years & São J. Rio Preto \\
\hline Government 01 & $07 / 10 / 15$ & In person & Director & 30 years & São J. Rio Preto \\
\hline $\begin{array}{l}\text { Government 01 } \\
\text { Farmer } \\
\text { Processer 01 and }\end{array}$ & $07 / 10 / 15$ & In person & Agronomist & 10 years & São J. Rio Preto \\
\hline
\end{tabular}




\begin{tabular}{l|l|l|l|l|l}
\hline $\begin{array}{l}\text { Farmer } \\
\text { Processer 02 }\end{array} \quad$ and & $17 / 11 / 15$ & Skype & Owner & 17 years & Capivari \\
\hline $\begin{array}{l}\text { Farmer } \\
\text { Processer 03 }\end{array} \quad$ and & $13 / 11 / 15$ & Skype & Owner & 10 years & Arealva \\
\hline Processer 04 & $04 / 12 / 15$ & In person & Sustainability Manager & 04 years & Pirassununga Co \\
\hline Processer 05 & $03 / 10 / 15$ & Skype & Purchases Manager & 03 years & Santa C R. Pardo \\
\hline Processer 05 & $03 / 10 / 15$ & Skype & Agriculture Director & 30 years & Santa C R. Pardo \\
\hline Plant 05 & $07 / 10 / 15$ & In person & Agriculture Manager & 20 years & Novo Horizonte \\
\hline Cooperative 01 & $23 / 10 / 15$ & Skype & Agriculture Manager & 42 years & Bebedouro \\
\hline
\end{tabular}

$\underline{2}^{\text {nd }}$ Phase of Collection

\begin{tabular}{|c|c|c|c|c|c|}
\hline Chain links & Date & Interview type & Respondent position & Experience & City \\
\hline Government 01 & & Skype & Director & 31 years & São J. Rio Preto \\
\hline Government 01 & & Skype & Agronomist & 11 years & São J. Rio Preto \\
\hline Association 01 & $24 / 10 / 16$ & In person & $\begin{array}{ll}\text { Water } & \text { Resources } \\
\text { Consultant } & \end{array}$ & 12 years & São Paulo \\
\hline $\begin{array}{ll}\text { Farmer } & \text { and } \\
\text { Processer } 01 & \end{array}$ & $28 / 10 / 16$ & Skype & Owner & 13 years & Cerquilho \\
\hline $\begin{array}{ll}\text { Farmer } & \text { and } \\
\text { Processer } 02 & \end{array}$ & $27 / 10 / 16$ & Skype & Owner & 18 years & Capivari \\
\hline Farmer 04 & $03 / 11 / 16$ & In person & Owner & 20 years & Ribeirão Preto \\
\hline Processer 04 & $10 / 11 / 16$ & In person & Agriculture Manager & 12 years & Porto Ferreira \\
\hline Processer 04 & $10 / 11 / 16$ & In person & Industrial Manager & 20 years & Porto Ferreira \\
\hline Processer 04 & $29 / 11 / 16$ & Skype & Sustainability Manager & 05 years & Pirassununga \\
\hline Processer 05 & & Skype & Agriculture Director & 31 years & Santa C R. Pardo \\
\hline Plant 01 & $17 / 10 / 16$ & Skype & Agriculture Manager & 07 years & Descalvado \\
\hline Plant 02 & $31 / 10 / 16$ & In person & Director of Operations & 12 years & Lençóis Paulista \\
\hline Plant 03 & $03 / 11 / 16$ & In person & Director of Operations & 03 years & Ribeirão Preto \\
\hline Plant 03 & $03 / 11 / 16$ & In person & $\begin{array}{l}\text { Superintendent } \\
\text { Operations }\end{array}$ & 03 years & Ribeirão Preto \\
\hline Plant 04 & $28 / 11 / 16$ & In person & Legal Manager & 12 years & Sandovalina \\
\hline Plant 04 & $07 / 11 / 16$ & Skype & Supply Chain Manager & 12 years & Sandovalina \\
\hline Plant 05 & $21 / 11 / 16$ & In person & Agriculture Manager & 21 years & Novo Horizonte \\
\hline Plant 06 & $25 / 11 / 16$ & Skype & Production Manager & 09 years & Pitangueiras \\
\hline Plant 07 & $25 / 11 / 16$ & Skype & Agriculture Manager & 13 years & Ariranha \\
\hline Plant 08 & $31 / 10 / 16$ & In person & Environmental Director & 12 years & São Manuel \\
\hline Plant 08 & $31 / 10 / 16$ & In person & Environmental Manager & 12 years & São Manuel \\
\hline Plant 08 & 01/11/16 & In writing & Supervisor of Utilities & 07 years & São Manuel \\
\hline Cooperative 01 & & Skype & Agriculture Manager & 43 years & Bebedouro \\
\hline Cooperative 02 & $04 / 11 / 16$ & Skype & Institutional Assistant & 03 years & São Paulo \\
\hline Cooperative 02 & $22 / 11 / 16$ & Skype & Sustainability Manager & 04 years & São Paulo \\
\hline Bever. Network 01 & $18 / 11 / 16$ & Skype & Purchases Manager & 07 years & São Paulo \\
\hline Bever. Network 02 & $30 / 11 / 16$ & Skype & Quality Manager & 09 years & Leme \\
\hline Foods Network 01 & $18 / 11 / 16$ & In person & Sustainability Manager & 05 years & São Paulo \\
\hline
\end{tabular}

Source: Research Data 
In some cases the interviews, which were recorded, had more than one interviewee, which enabled validating information; additionally, whenever possible, they were conducted by two researchers in order to increase internal validity (Barratt, Choi, \& Li, 2011; Eisenhardt, 1989). It is worth stressing also that for triangulation purposes, documents' data and Web sources (e.g., organization's websites, reports and information bulletins) equally served as source of research. Exhibit 3 presents a summary of the criteria previously adopted to increase reliability of this research's findings.

\section{Exhibit 3. Reliability of the Case Study's Findings}

\begin{tabular}{|c|c|}
\hline Reliability criteria & Method used in this study \\
\hline $\begin{array}{l}\text { Credibility (to what extent the findings } \\
\text { seem to be acceptable representations } \\
\text { of the data) }\end{array}$ & $\begin{array}{l}\text { - Research protocol used based on questions referring to literature } \\
\text { on resilience in supply chain. } \\
\text { - Two researchers collected data simultaneously during the first } \\
\text { phase of collection; and all researchers analyzed the data. } \\
\text { A 3-page executive summary of the initial interpretations was } \\
\text { held out to respondents for feedback. }\end{array}$ \\
\hline $\begin{array}{l}\text { Generalization of findings (to what } \\
\text { extent the findings of a study within } \\
\text { a context are applicable to other } \\
\text { contexts) }\end{array}$ & $\begin{array}{l}\text { - Limits for generalization once it is a simple case study based on } \\
\text { the supply chain of sugar, biomass energy, biofuels and spirits or } \\
\text { soft drinks. } \\
\text { Examples of companies in different links of the supply chain } \\
\text { represented by the Farmers, Processers and Buyers triad. }\end{array}$ \\
\hline $\begin{array}{l}\text { Reliability (extension exclusive to time } \\
\text { and place; stability or consistence of } \\
\text { explanations ) }\end{array}$ & $\begin{array}{l}\text { - Interviewees reported experiences covering the phenomenon } \\
\text { studied (drought) and historical data of other serious events. } \\
\text { Data collection in two periods with a one-year interval between } \\
\text { them with participation of other informants of the first phase } \\
\text { in the second phase of the data collection (except Farmer and } \\
\text { Processer 3). } \\
\text { - Interviewing more than one subject per company was always } \\
\text { possible, but all with more than three-year experience. } \\
\text { Triangulation with association and Government and with } \\
\text { documents and observations in the field. }\end{array}$ \\
\hline
\end{tabular}

Possibility of confirmation (to what extent the interpretations are the outcome of the participants' information and of the phenomenon instead of the researcher's bias)
- All interviews and documents were analyzed by the authors

- Summary of preliminary findings were analyzed by other team members performing as controllers.

Source: Adapted (Flint, Woodruff, \& Gardial, 2002; Kaufmann \& Denk, 2011)

\section{ANALYSIS OF FINDINGS}

The interviews were analyzed by using the CAQDAS (Computer Assisted Qualitative Data Analysis Software), with the N-Vivo software, and were grouped in categories, by using Microsoft Excel to create different tables by following the tactics suggested by Miles, Huberman, \& Saldaña (2014) to create significance, such as, for instance, searching for patterns, grouping information, elaborating metaphors, counting, elaborating comparisons, checking relationships among variable "types of collaboration", searching for other variables causing interferences, building up logical replication of evidence and elaborating conceptual and theoretical coherence.

The first data reduction happened for the purposes of selecting, among interviewees' speeches, sentences and/or paragraphs that were actually important to answer the research question (in vivo codes). The categories mostly found were: (1) information sharing (absorptive capacity of a partner and incentives to encourage transparency and discourage free agreements), (2) efforts to make joint relationships (ability to identify and assess potential of complementarities and the role performed by organiza- 
tional complementarities to access complementary strategic resources), and (3) dedicated investments (duration of contractual guaranties and volume of transactions among the companies).

Information sharing among producers in the sugarcane-energy supply chain is not significant, and none of the participating producers presented any evidence of any partnership made, mainly due to the drought. One of the sugarcane producers, a mediumsized company, used as an example the exchange of sugarcane for vinasse for fertigation because logistic costs of transportation and storage of that product make establishing any collaboration among the chain links impossible.

Although the byproduct is abundantly available to the plants, among them and producers no efforts are made for a joint relationship, except Plant 02, which buys directly from a partner, an agriculture company, in a collaborative way. In the remaining cases collaboration of producers is limited to holding meetings and speeches with associations of regional producers.

As to distilleries, little collaboration was also verified.

The agriculture manager of a large distillery mentions that there was no collaboration to regulate supply during the drought period, mainly due to the strong competition with the remaining plants near the distillery: "we are eight plants around here, see, then there was not collaboration whatsoever, it was a race to come first, it was each one by himself" (agriculture manager of a large distillery).

And still according to that participant, lack of collaboration is caused by historical cultural traits represented by the character of the owners of the first sugarcane-energy plants, the so-called "colonels". According to him, that stance prevents the development of many regions due to competition related to labor, and he alleged that at places where there are many plants there was no other developing industries.

The large distillery's participant managers state that although some groups and research centers have been set up, the sugarcane-energy supply chain remains isolated, its potential is not totally recognized in the global market. Among the barriers to development, in their opinion, there is the government intervention in the sector through subsidies favoring fuel, energy and sugar commercialization.

Not always can the plants take advantage of the benefits to promote long-term integration and structur- ing. The technical manager of plant 6 confirms the need of more collaboration, and justifies that due to lack thereof some plants have been shut down during the drought, exactly as a result of bad administration and lack of governmental support. Among them, two different scenarios were observed: at the plant not associated to cooperative 2, due to lack of any relationship action with the producer, there were major difficulties with the resulting economic problems (high prices of raw material) and financial ones (lack of capital for investment).

At the plants linked to cooperative 2, on their turn, sharing information took place through joint efforts for relationship, such as periodical meetings and dedicated investments: e.g., infrastructure to store cooperative 2's sugar, available at many plants, pointed out as a competitive advantage for its flexibility and co-location, in addition to information systems developed between cooperative 2 and the associated supplying plants.

One of the participants, an agriculture manager of plant 1 , stresses that the information coming from cooperative 2 would circulate only internally in the company, but the use of new technologies related to the internet had helped their fast diffusion to the interested parties in the sugarcane-energy sector.

Plant 3 said that information was shared during the drought among the State Department of the Environment (SMA), Environmental Company of the State of São Paulo (CETESB) and the Department of Water and Electricity (DAEE), at meetings attended by experts of the Sugarcane Technology Center (CTC) to start defining joint plans.

As to buyers, food network 1 says that permanent internal committees were formed to follow the matters related to climate and sustainable use of the water, in addition to external relationships between plants of the food network and their suppliers through debates and assessments. Still in the opinion of the buyers, other organizations represented, such as the soft drink network 1 , point out that some of its buyers demand sharing information on products and management of natural resources (which was done through emails both to buyers and to governmental inspection agencies).

Efforts for a joint relationship among companies in the sugarcane-energy supply chain were strongly evidenced between the plants (except for plant 7, not associated) and cooperative 2 . 
In addition to those pieces of evidence of vertical collaboration, efforts for joint relationship are very common between plants and research center or Institutions of Superior Education (IES), which also strengthen horizontal collaboration. Plant 2 says that it developed, in a partnership with the Superior School of Agriculture Luiz de Queiroz (ESALQ), a new soil systematization, with new technology to prepare and deepen roots: "we worked together with ESALQ, and we drew a new soil systematization and, in parallel, we made that preparation of deep soil, which is a new technology that we brought to the sector" (director of operations, plant 2).

Those efforts for a joint relationship have enabled plant 2 to develop follow-up tools which ease conducting analyses in order to increase predictability of information before making decisions. The director of operations highlighted also that the efforts for a joint relationship among plants, cooperative 1 and association of the industry enable the company to have opportunities to develop partnerships with international non-governmental organizations, such as the "Water Project", in a partnership with the World Wildlife Fund (WWF).

The superintendent of operations of plant 3 highlights another example of efforts for a joint relationship, but with companies outside the sugarcane supply chain targeting on emergencies in case of fire or burning, which are more usual during long dry periods.

The agriculture manager of plant 5 confirms the importance of those partnerships between research centers and superior education institutions focused on developing new technologies for handling varieties of sugarcane in the tillage, more resistant to pests and bad weather caused by the climate. Participant of cooperative 2 points out the Center of Sugarcane Technology (CTC) as an important link in the development of new varieties, although they are not oriented towards commercial demand. As to buyers, food network 1 relies on a research and development center and has contacts with suppliers aimed at creating, among other things, machinery to bottle products according to economic, social and environmental indicators.

And still as to buyers, food chain 1 confirmed that partnerships are made with its suppliers at each new product line launched for the purposes of assessing the use of water, fuel and electricity, among other utilities, thus corroborating the existence of strong vertical collaboration among them. The participant comments that it was necessary to set up standard procedures elaborated based on the response used at the plants in more critical situations.

According to that participant, the drought led to the creation of a permanent group at the holding company in charge of controlling food network 1 and developing several indicators to follow up the management of water resources among the companies of that holding company. He also adds that the relationship does not reach any third parties (considering the triad farmers, processers and buyers) and, for now, there has been only some approximation among suppliers related to that process; nevertheless, there was an alert about the negative impacts of a drought, and proposals started to be made in 2016, but they were not complete during the data collection from July to November 2016).

Finally, about dedicated investments, although there was no mention about the absence of information sharing at the large distillery among processers and producers, investments were pointed out with other partners linked to agricultural production and industrial process. "Everything that we could observe that was important we had already searched for. There are projects with heavy investments and so on, but there is nothing like that, imagine if I had it, no" (large distillery's agriculture manager).

On the other hand, for medium-sized sugarcane producers the companies performing in the sugarcaneenergy sector have to be more united and government leadership is missing. The quality manager of plant 7 stresses, in this sense, that there is a bureaucratic barrier and also a decrease in long-term credit lines for renewing sugarcane plantations.

The sugarcane-energy supply chain has low incidence of pests (when compared to other cultures, such as orange, for instance) and in its cultivation it is necessary to work with the dry periods, which are positive up to a point, both for the product quality, once it increases sucrose, and to logistics, i.e., mechanical harvesting, a process that may be unfeasible during the rainy period.

The sustainability manager of cooperative 1 points out that the plant participates in meetings to deal with matters related to quality and sustainability. According to her, her area collaborates internally with the quality sector aiming at implementing actions and qualification, and at mobilizing the plants. Using the information shared with the plants, how- 
ever, is relative because ones are more interested than others. Cooperative 2 reported that case studies have been used at the plants with the best practices in order to share information before and during the drought.

Collaboration was used for the following actions at the plants during the response phase: (1) developing technology to concentrate vinasse for fertigation, (2) enhancing practices to handle varieties, i.e., looking for genetic development of sugarcane young plants more resistant to water stress, or yet, (3) innovating plating processes by using pre-sprouted plants (PSP) and developed in nurseries (meiosis). During the recovery phase were pointed out (4) soil conservation practices, such as systematization of use of terraces to prevent soil erosion and which are able to retain more water to supply the groundwater and, consequently, the springs.

Exhibit 4 presents evidence of the byproducts facilitating collaboration in the sugarcane-energy supply chain obtained in the interviews conducted.

\section{Exhibit 04. Sub-processes facilitating collaboration in the sugarcane-energy supply chain}

\begin{tabular}{l|l|l|l}
\hline $\begin{array}{c}\text { Aspects } \\
\text { determining } \\
\text { collaboration }\end{array}$ & $\begin{array}{c}\text { Facilitating sub- } \\
\text { processes }\end{array}$ & $\begin{array}{l}\text { Examples Sugarcane-energy } \\
\text { supply chain }\end{array}$ & \multicolumn{1}{c}{ In vivo codification } \\
\hline \multirow{2}{*}{$\begin{array}{l}\text { Duration of } \\
\text { contractual } \\
\text { guaranties } \\
\text { specific assets }\end{array}$} & $\begin{array}{l}\text { Contracts with farmers } \\
\text { usually last five years with few } \\
\text { sugarcane left for negotiations } \\
\text { at the in-cash market }\end{array}$ & $\begin{array}{l}\text { "When the drought came, } \\
\text { there was no sugarcane in } \\
\text { the market and everybody } \\
\text { started panicking " (Agriculture } \\
\text { Manager Processer 4) }\end{array}$ \\
\cline { 2 - 4 } & $\begin{array}{l}\text { Volume of } \\
\text { transactions among } \\
\text { companies }\end{array}$ & $\begin{array}{l}\text { Plants have contracts with } \\
\text { Cooperative 2 for exports and } \\
\text { large volumes for the internal } \\
\text { market, including the soft drink } \\
\text { network 1, which participated in } \\
\text { the research, was mentioned }\end{array}$ & $\begin{array}{l}\text { "The major part of our products, } \\
\text { national market, the soft drink } \\
\text { network 1, buyer 2, buyer } \\
\text { 3, usually are traditional, } \\
\text { structured companies and } \\
\text { they also are concerned about } \\
\text { their supply chain" (Director of } \\
\text { Operations Plant 3). }\end{array}$ \\
\hline
\end{tabular}




\begin{tabular}{|c|c|c|c|}
\hline \multirow{5}{*}{$\begin{array}{l}\text { Information- } \\
\text { sharing routines }\end{array}$} & \multirow{3}{*}{$\begin{array}{l}\text { Absorbing capacity } \\
\text { of a partner }\end{array}$} & $\begin{array}{l}\text { Plant belongs to an international } \\
\text { group with over } 100 \text {-year } \\
\text { experience with international } \\
\text { agriculture commodities }\end{array}$ & $\begin{array}{l}\text { "As we have an international } \\
\text { partnership controlling us, } \\
\text { including crossing information } \\
\text { of crops from other regions, } \\
\text { Thailand, Australia, as to this } \\
\text { aspect we are rather solid" } \\
\text { (Superintendent Plant 3). }\end{array}$ \\
\hline & & $\begin{array}{l}\text { Plant points out that the } \\
\text { research centers and } \\
\text { associations of the industry are } \\
\text { important, but they used to } \\
\text { have more resources }\end{array}$ & $\begin{array}{l}\text { "Maybe the aspect that } \\
\text { could improve a little is the } \\
\text { issue of the best practices, } \\
\text { benchmarking. The CTC used } \\
\text { to play that role" (Director de } \\
\text { Operations Plant 3) }\end{array}$ \\
\hline & & $\begin{array}{l}\text { Cooperative Buyer shows } \\
\text { that they work with internal } \\
\text { relationship once they are inter- } \\
\text { functionality oriented }\end{array}$ & $\begin{array}{l}\text { "Actually this is a subject } \\
\text { approached by the quality } \\
\text { area, where we raise the } \\
\text { subject, as we do with } \\
\text { sustainability" (Sustainability } \\
\text { Manager, Cooperative 2) }\end{array}$ \\
\hline & \multirow{2}{*}{$\begin{array}{l}\text { Incentives to } \\
\text { encourage } \\
\text { transparency and } \\
\text { discourage free } \\
\text { agreements }\end{array}$} & $\begin{array}{l}\text { Foods network participates in } \\
\text { the international program for } \\
\text { carbon-emission reduction }\end{array}$ & $\begin{array}{l}\text { "We participate in the CDP, } \\
\text { I don't know if you have } \\
\text { ever heard of it, it is a global } \\
\text { platform where industries } \\
\text { declare their strategic plans } \\
\text { related to the hydric crises, } \\
\text { energy crises" (Sustainability } \\
\text { Manager Foods network 1) }\end{array}$ \\
\hline & & $\begin{array}{l}\text { Cooperative } 2 \text { holds meetings } \\
\text { about more critical matters to } \\
\text { prepare action plans together } \\
\text { with the cooperated plants }\end{array}$ & $\begin{array}{l}\text { "Then those are actually more } \\
\text { critical matters, but the quality } \\
\text { also has no direct action on } \\
\text { the plants. So they discuss } \\
\text { the matter, deal with it and } \\
\text { guide what has to be done: } \\
\text { let's prepare an action plan" } \\
\text { (Cooperative 2). }\end{array}$ \\
\hline $\begin{array}{l}\text { Complementary } \\
\text { capacities and } \\
\text { resources }\end{array}$ & $\begin{array}{l}\text { Capacity to } \\
\text { identify and assess } \\
\text { complementarities' } \\
\text { potential }\end{array}$ & $\begin{array}{l}\text { Plant discloses it learned during } \\
\text { the drought by searching other } \\
\text { sources of improvement }\end{array}$ & $\begin{array}{l}\text { "Crises help you search other } \\
\text { sources of improvement. One } \\
\text { thing is the crisis, hydric crisis, } \\
\text { for instance, the drought which } \\
\text { does not depend on you, } \\
\text { everybody ends up thinking } \\
\text { "what can I do to improve } \\
\text { independence from the } \\
\text { weather?", and they end up by } \\
\text { taking other complementary } \\
\text { actions, and when they } \\
\text { move, they do not come back } \\
\text { to the previous level, they } \\
\text { even move to a higher level" } \\
\text { (Superintendent Plant 3). }\end{array}$ \\
\hline
\end{tabular}




\begin{tabular}{|c|c|c|c|}
\hline \multirow{4}{*}{$\begin{array}{l}\text { Effective } \\
\text { governance }\end{array}$} & \multirow{3}{*}{$\begin{array}{l}\text { Capacity to use self- } \\
\text { application instead } \\
\text { of application by } \\
\text { third parties of } \\
\text { the governance } \\
\text { mechanisms }\end{array}$} & $\begin{array}{l}\text { Plants have governance } \\
\text { mechanisms in place together } \\
\text { with Cooperative } 2\end{array}$ & $\begin{array}{l}\text { "(...) for instance, in the audit's } \\
\text { checklist, this environmental } \\
\text { issue, social liability, mainly } \\
\text { related to the environment, } \\
\text { related to the community, } \\
\text { how we are dealing with } \\
\text { those crises. I mean, we have } \\
\text { realized that it started to be } \\
\text { something..." (Plant 3). }\end{array}$ \\
\hline & & $\begin{array}{l}\text { Plants have their own norms and } \\
\text { certifications }\end{array}$ & $\begin{array}{l}\text { "And there is also the } \\
\text { certifications we have, } \\
\text { BONSUCRO, green } \\
\text { ethanol, directly related to } \\
\text { sustainability" Plant 3). }\end{array}$ \\
\hline & & $\begin{array}{l}\text { Cooperative informs that the } \\
\text { plants make their own decisions } \\
\text { about engaging in actions } \\
\text { related to sustainability }\end{array}$ & $\begin{array}{l}\text { "We actually do not have a } \\
\text { direct management, and that } \\
\text { is why I said that if the plant } \\
\text { is not willing to engage, it } \\
\text { doesn't engage. Not all of } \\
\text { them engage in the same } \\
\text { way". (Sustainability Manager } \\
\text { Cooperative 2) }\end{array}$ \\
\hline & $\begin{array}{l}\text { Capacity to use } \\
\text { self-applicable } \\
\text { formal and informal } \\
\text { governance } \\
\text { mechanisms }\end{array}$ & $\begin{array}{l}\text { Cooperative } 2 \text { has formal and } \\
\text { informal self-applicable on } \\
\text { cooperated plant suppliers }\end{array}$ & $\begin{array}{l}\text { "There is a formal area in the } \\
\text { company which actually raises } \\
\text { those pieces of information } \\
\text { and is actually in charge } \\
\text { of supplying the market, } \\
\text { making contact with clients } \\
\text { and areas such as quality and } \\
\text { sustainability, they deal with } \\
\text { the matter more broadly. } \\
\text { Then we see the matter, work } \\
\text { on it, gather the plants and } \\
\text { discuss the importance of the } \\
\text { matter, what is to be done, } \\
\text { what we could do, we listen } \\
\text { to them some and take some } \\
\text { information from where we are } \\
\text { being charged, from where the } \\
\text { matter is gaining importance. } \\
\text { There are two different ways of } \\
\text { acting" (Cooperative 2) }\end{array}$ \\
\hline
\end{tabular}

Source: Adapted (Dyer \& Singh, 1998; Paulraj et al., 2012) 


\section{FINAL CONSIDERATIONS}

Comparing the capacity of collaboration of the links in the sugarcane-energy supply chain, buyers have strong capacity of collaborating with plants (processers), observed at all phases of the drought, mainly in the sample studied here which involves, among the organizations participating in this study, a global network of soft drink manufacturers and a cooperative which trades sugar worldwide.

In the case of the plants associated to that cooperative, the collaboration capacity was observed in the examples of information sharing deemed relevant for the chain in addition to joint efforts for relationships, dedicated investments and effective governance representing the status of the practice of collaboration in supply chains (Dyer \& Singh, 1998; Nyaga, Whipple, \& Lynch, 2010; Paulraj et al., 2012).

The weak link of collaboration lies in the farmers' position (producers), who receive the information shared at meetings, workshops, weather forecasts in the Internet, but without coming closer enough to make joint efforts and dedicated investments, little horizontal and vertical collaboration being highlighted (Barratt, 2004).

In the phase of response to the drought, more approximation was observed caused by the possibility of having some plants shut down. Horizontal collaboration composed by government agencies, sector associations and research centers during that period was strengthened because information was shared, dedicated efforts and investments in monitoring hydrographical basins were made, in addition to researches to develop new plant varieties and preserve water resources.

On the other hand, horizontal collaboration was weakened due to an increase in competition for water resources among plants and distilleries. The findings in this case study of the sugarcane-energy supply chain of São Paulo can be valid within this specific context. Due to the interdependence of the uncertainty and the processes to make economic decisions, future studies can compare organizations located at different regions where they face the drought, in addition to different agribusiness cultures.

\section{NOTE FROM THE EDITOR}

This article was presented at the XX Simpósio de Administração da Produção, Logística e Operações Internacionais in 2017

\section{REFERENCES}

Ali, A., Mahfouz, A., \& Arisha, A. (2017). Analysing supply chain resilience: integrating the constructs in a concept mapping framework via a systematic literature review. Supply Chain Management: An International Journal, 22(1), 16-39. doi:10.1108/SCM-06-2016-0197

Ambulkar, S., Blackhurst, J., \& Grawe, S. (2015). Firm's resilience to supply chain disruptions: Scale development and empirical examination. Journal of Operations Management, 33-34, 111-122. doi:10.1016/j.jom.2014.11.002

Aquila, G., de Oliveira Pamplona, E., de Queiroz, A. R., Junior, P. R., \& Fonseca, M. N. (2017). An overview of incentive policies for the expansion of renewable energy generation in electricity power systems and the Brazilian experience. Renewable and Sustainable Energy Reviews, 70, 1090-1098.

Barratt, M. (2004). Understanding the meaning of collaboration in the supply chain. Supply Chain Management: An International Journal, 9(1), 30-42. doi:10.1108/13598540410517566

Barratt, M., Choi, T. Y., \& Li, M. (2011). Qualitative case studies in operations management: Trends, research outcomes, and future research implications. Journal of Operations Management, 29(4), 329-342. doi:10.1016/j.jom.2010.06.002

Biazzin, C., Paiva, E. L., Di Serio, L. C., \& De Andrade, M. C. F. (2015). Is There a Bitter Flavor in Sustainability for the Sugar-Alcohol Industry? Journal of Operations and Supply Chain Management, 8(1), 46-56. doi:10.12660/joscmv8n1p46-56

Blackhurst, J., Dunn, K. S., \& Craighead, C. W. (2011). An Empirically Derived Framework of Global Supply Resiliency. Journal of Business Logistics, 32(4), 374-391. doi:10.1111/ j.0000-0000.2011.01032.x

Brunhara, J. P. C., Corrêa, R. P., \& Mazini, S. R. (2018). Cleaner Production in the Brazilian Sucroenergy Sector. In Green Production Strategies for Sustainability (pp. 72-91). IGI Global.

Cao, M., \& Zhang, Q. (2011). Supply chain collaboration: Impact on collaborative advantage and firm performance. Journal of Operations Management, 29(3), 163-180. doi:10.1016/j.jom.2010.12.008

Christopher, M., \& Peck, H. (2004). Building the resilience supply chain. International Journal of Logistics Management, 15(2), 1-13. doi:10.1080/13675560600717763

de Almeida, L. Q., Welle, T., \& Birkmann, J. (2016). Disaster risk indicators in Brazil: A proposal based on the world risk index. International Journal of Disaster Risk Reduction, 17, 251-272. doi:10.1016/j.ijdrr.2016.04.007

de Souza Dias, M. O., Maciel Filho, R., Mantelatto, P. E., Cavalett, O., Rossell, C. E. V., Bonomi, A., \& Leal, M. R. L. V. (2015). Sugarcane processing for ethanol and sugar in Brazil. Environmental Development, 15, 35-51. doi:10.1016/j. envdev.2015.03.004

Dyer, J. H., \& Singh, H. (1998). The relational view: cooperative strategy and sources of interorganizational competitive advantage. Academy of Management Review, 23(4), 660679. 
Eisenhardt, K. M. (1989). Building Theories from Case Study Research. Academy of Management Review, 14(4), 532-550. doi:10.5465/AMR.1989.4308385

Flint, D. J., Woodruff, R. B., \& Gardial, S. F. (2002). Exploring the Phenomenon of Customers' Desired Value Change in a Business-to-Business Context. Journal of Marketing, 66(4), 102-117. doi:10.1509/jmkg.66.4.102.18517

Fuess, L. T., Rodrigues, I. J., \& Garcia, M. L. (2017). Fertirrigation with sugarcane vinasse: Foreseeing potential impacts on soil and water resources through vinasse characterization. Journal of Environmental Science and Health, Part A, 52(11), 1063-1072.

Hahn, T., Pinkse, J., Preuss, L., \& Figge, F. (2015). Tensions in Corporate Sustainability: Towards an Integrative Framework. Journal of Business Ethics, 127(2), 297-316. doi:10.1007/s10551-014-2047-5

Julca-Briceño, B. M., \& Fava Neves, M. (2011). Caracterización de sistemas agroindustriales: un estudio comparativo de los sectores sucroenergéticos de Brasil y Colombia. Interciencia, 36(5).

Jüttner, U. (2005). Supply chain risk management: Understanding the business requirements from a practitioner perspective. The International Journal of Logistics Management. doi:10.1108/09574090510617385

Jüttner, U., \& Maklan, S. (2011). Supply chain resilience in the global financial crisis: an empirical study. Supply Chain Management: An International Journal, 16(4), 246-259. doi:10.1108/13598541111139062

Kamalahmadi, M., \& Parast, M. M. (2016). A review of the literature on the principles of enterprise and supply chain resilience: Major findings and directions for future research. International Journal of Production Economics, 171, 116-133. doi:10.1016/j.ijpe.2015.10.023

Kaufmann, L., \& Denk, N. (2011). How To Demonstrate Rigor When Presenting Grounded Theory Research in the Supply Chain Management Literature, 47(4).

Knemeyer, A. M., Zinn, W., \& Eroglu, C. (2009). Proactive planning for catastrophic events in supply chains. Journal of Operations Management, 27(2), 141-153. doi:10.1016/j. jom.2008.06.002

Leat, P., \& Revoredo-Giha, C. (2013). Risk and resilience in agrifood supply chains: the case of the ASDA PorkLink supply chain in Scotland. Supply Chain Management: An International Journal, 18, 219-231. doi:10.1108/13598541311318845

Masuku, M. B., Kirsten, J. F., Rooyen, C. J. Van, \& Perret, S. (2003). Contractual relationships between small-holder sugarcane growers and millers in the sugar industry supply chain in Swaziland. Agrekon, 42(September 2003), 183199. doi:10.1080/03031853.2003.9523619

Miles, M. B., Huberman, A. M., \& Saldaña, J. (2014). Qualitative Data Analysis. A Methods Sourcebook (Vol. 28). Sage publications.

Nobre, C. A., Marengo, J. A., Seluchi, M. E., Cuartas, L. A., \& Alves, L. M. (2016). Some Characteristics and Impacts of the Drought and Water Crisis in Southeastern Brazil during 2014 and 2015. Journal of Water Resource and Protection, 8(02), 252-262. doi:10.4236/jwarp.2016.82022

Nyaga, G. N., Whipple, J. M., \& Lynch, D. F. (2010). Examining supply chain relationships: Do buyer and supplier perspectives on collaborative relationships differ? Journal of Operations Management, 28(2), 101-114. doi:10.1016/j. jom.2009.07.005

Odongo, W., Dora, M., Molnár, A., Ongeng, D., \& Gellynck, X. (2016). Performance perceptions among food supply chain members. British Food Journal, 118(7), 1783-1799. doi:10.1108/BFJ-10-2015-0357

Paulraj, A., Chen, I. J., \& Lado, A. A. (2012). An empirical taxonomy of supply chain management practices. Journal of Business Logistics, 33(3), 227-244.

Pettit, T. J., Croxton, K. L., \& Fiksel, J. (2013). Ensuring supply chain resilience: Development and implementation of an assessment tool. Journal of Business Logistics, 34(1), 46-76. doi:10.1111/jbl.12009

Pettit, T. J., Fiksel, J., \& Croxton, K. L. (2010). Ensuring Supply Chain Resilience: Development of a Conceptual Framework. Journal of Business Logistics, 31(1), 1-21. doi:10.1002/j.2158-1592.2010.tb00125.x

Pivetta, M. (2016a). Calamidades na América do Sul. Pesquisa Fapesp, 241(Março), 62-65.

Pivetta, M. (2016b). Um Brasil mais vulnerável no século XXI. Pesquisa Fapesp, 249(Novembro), 16-23.

Ponomarov, S. Y., \& Holcomb, M. C. (2009). Understanding the concept of supply chain resilience. The International Journal of Logistics Management, 20(1), 124-143. doi:10.1108/09574090910954873

Prima Dania, W. A., Xing, K., \& Amer, Y. (2016). Collaboration and Sustainable Agri-Food Suply Chain: A Literature Review. MATEC Web of Conferences, 58, 02004. doi:10.1051/ matecconf/20165802004

Punniyamoorthy, M., Thamaraiselvan, N., \& Manikandan, L. (2013). Assessment of supply chain risk: scale development and validation. Benchmarking: An International Journal, 20(1), 79-105. doi:10.1108/14635771311299506

Rice, J. B., \& Caniato, F. (2003). Building a secure and resilient supply network. Supply Chain Management Review, 7(5), 22-30.

Scholten, K., Schilder, S., \& Wagner, B. (2015). The role of collaboration in supply chain resilience. Supply Chain Management: An International Journal, 20(4). Retrieved from http://www.emeraldinsight.com/doi/pdfplus/10.1108/ SCM-11-2014-0386

Sodhi, M. S., \& Lee, S. (2007). An analysis of sources of risk in the consumer electronics industry. Journal of the Operational Research Society, 58(11), 1430-1439. doi:10.1057/ palgrave.jors. 2602410

Stecke, K. E., \& Kumar, S. (2009). Sources of Supply Chain Disruptions, Factors That Breed Vulnerability, and Mitigating 
79 AUTHORS | Marcelo Martins de Sá| Susana Farias Pereira | Priscila Lacsynski de Souza Miguel

Strategies. Journal of Marketing Channels, 16(3), 193-226. doi:10.1080/10466690902932551

Stevenson, M., \& Spring, M. (2007). Flexibility from a supply chain perspective: definition and review. International Journal of Operations \& Production Management (Vol. 27). doi:10.1108/01443570710756956

Sullivan-Taylor, B., \& Branicki, L. (2011). Creating resilient SMEs: Why one size might not fit all. International Journal of Production Research, 49(18), 5565-5579. doi:10.1080/00 207543.2011.563837

Tukamuhabwa, B. R., Stevenson, M., Busby, J., \& Zorzini, M. (2015). Supply chain resilience: definition, review and the- oretical foundations for further study. International Journal of Production Research, 53(18), 5592-523. doi:10.1080/002 07543.2015.1037934

Wieland, A., \& Wallenburg, C. M. (2013). The influence of relational competencies on supply chain resilience: a relational view. International Journal of Physical Distribution \& Logistics Management, 43(4), 300-320. doi:10.1108/IJPDLM-08-2012-0243

Zacharia, Z. G., Nix, N. W., \& Lusch, R. F. (2009). An analysis of supply chain collaborations and their effect on performance outcomes. Journal of Business Logistics, 30(2), 101123. doi:10.1002/j.2158-1592.2009.tb00114.x 